\title{
Survey on Tip-over Disease of Banana caused by Erwinia carotovora subsp. Carotovora (Jones) Holland in Parts North Eastern Karnataka, India
}

\author{
V. Thiyagarajan ${ }^{1 *}$, S.T. Yenjerappa ${ }^{1}$, Gururaj Sunkad ${ }^{1}$, D.S. Aswathanarayana ${ }^{1}$, \\ V. Karuppaiah ${ }^{2}$ and H.M. Shaila ${ }^{1}$ \\ ${ }^{1}$ Department of Plant Pathology, College of Agriculture, Raichur, University of \\ Agricultural Sciences, Raichur, India \\ ${ }^{2}$ Directorate of Onion and Garlic Research, Pune, India \\ *Corresponding author
}

\begin{tabular}{|c|c|}
\hline & A B S T R A C T \\
\hline Keywords & \multirow{4}{*}{$\begin{array}{l}\text { Tip-over disease in Banana is an important bacterial disease caused by Erwinia carotovora } \\
\text { subsp. Carotovora. The disease cause severe yield loss in banana particularly in tissue } \\
\text { cultured plantations. A roving survey was conducted to assess the severity of tip-over } \\
\text { disease of Banana in the farmer's field of north eastern Karnataka. Survey reported highest } \\
\text { disease incidence ( } 20.35 \%) \text { at Muddaballi village of Koppal district. The least incidence } \\
(1.15 \%) \text { was recorded in Ankammanahal village of Sandur taluk of Bellary district. Taluk } \\
\text { wise mean incidence revealed that, highest disease incidence of } 17.92 \text { per cent was } \\
\text { recorded in Koppal followed by Shimoga ( } 12.0 \%) \text {, Gangavati }(8.07 \%) \text {, Holalkere }(7.8 \%) \\
\text { and Sagar }(6.30 \%) \text { taluks. The minimum incidence of } 1.75 \text { per cent was recorded in } \\
\text { Sandur, Hospet ( } 4.69 \%) \text {, Hiriyur (5.7\%) taluks. District-wise, highest tip over incidence of } \\
12.99 \text { was recorded from Koppal followed by Shimoga ( } 9.15 \%) \text { and Chitrdurga ( } 6.75 \%) \text {. } \\
\text { Lowest incidence of } 3.22 \text { per cent was recorded in Ballari district of Karnataka. The } \\
\text { survey revealed that, occurrence of Erwina carotovora in Banana varies with locations. }\end{array}$} \\
\hline $\begin{array}{l}\text { Bacterial disease } \\
\text { in banana, Musa } \\
\text { spp tip-over } \\
\text { disease, Erwinia } \\
\text { carotovora. }\end{array}$ & \\
\hline Article Info & \\
\hline $\begin{array}{l}\text { Accepted: } \\
29 \text { May } 2017 \\
\text { Available Online: } \\
\text { 10 June } 2017\end{array}$ & \\
\hline
\end{tabular}

\section{Introduction}

Banana (Musa spp.) is one of the oldest cultivated tropical fruit crops of India. It was known from the time immemorial as cheap, plentiful and most nourishing among all the fruits. Banana is generally grown throughout the country round the year. It is not a season bound crop and can be grown well under humid weather conditions. Several factors are attributed as constraints for successful production of banana and major being the occurrence of diseases. Banana is subjected to many serious debilitating diseases caused by fungi, viruses, bacteria, nematodes and nonparasitic agents.
Among the bacterial diseases, tip-over or bacterial rhizome rot caused by Erwinia caratovora sub sp. caratovora is gaining importance in recent years in Karnataka, as disease incidence was considerably over the years. A soft rot disease of banana referred to tip-over caused by Erwinia carotovora was recorded in Honduras in 1949 (Wardlaw, 1950 and Stover, 1959). Hildreth (1962) recorded losses in a range of $80-90 \%$ and maximum up to $93 \%$ in Gautemala. In India, this disease was reported by Edward et al., (1973). Khan and Nagaraj (1998) recorded the incidence of Tip-over disease of banana up to 
$70 \%$ in Karnataka. Keeping the view of distribution and prevalence of tip-over disease, the study was undertaken to estimate present status of disease incidence in major banana growing area of north eastern Karnataka.

\section{Materials and Methods}

An intensive roving survey was conducted during 2015-16, to know the disease incidence in North Eastern part of Karnataka viz., Koppal, Shimoga, Chitradurga and Ballari districts. In each of the district, two taluks were selected comprising two villages each and in each of the village, three plots were surveyed. In an orchard, banana plants were selected in zigzag manner and observations were made and recorded for the disease incidence using 0-5 scale.

The per cent disease incidence was calculated by employing the following formula

$$
\text { Per cent incidence }=\frac{\text { Number of plants infected }}{\text { Total number of plants observed }} \times 100
$$

During the survey, infected samples showing typical symptoms of tip over disease were collected and kept in polythene bags, brought to laboratory for further analysis.

\section{Results and Discussion}

Results of the survey revealed that, disease was noticed in all the locations surveyed with more or less incidence (Table 1-2). The highest tip over incidence of 20.35 per cent was recorded in Muddaballi village of Koppal district followed by 16.67 per cent in Bullapura, 15.50 per cent in Hatti villages of Shimoga and Koppal districts respectively. Moderate disease incidence ranged between 6.43 to 11.25 per cent was noticed in different villages viz; Kamalapura (6.43\%), Dharmapura (6.65\%), Garaga (7.23\%), Adur (8.35\%), Budipura (8.48\%) and Bennur $(11.25 \%)$ villages. Lowest incidence of 1.15 per cent was recorded in Ankammanahal village of Sandur taluk. Taluk wise mean incidence indicated that, highest disease incidence of 17.92 per cent was recorded in Koppal followed by Shimoga (12.0\%), Gangavati $(8.07 \%)$, Holalkere $(7.8 \%)$ and Sagar $(6.30 \%)$ taluks. Lowest incidence of
1.75 per cent was recorded in Sandur. Among the different districts, highest tip over incidence of 12.99 was recorded from Koppal followed by Shimoga $(9.15 \%)$ and Chitrdurga (6.75\%). Lowest incidence of 3.22 per cent was recorded in Ballari district. The survey report of the present investigation takes the support of several previous workers. Edward et al., (1973), noticed the tip-over incidence in a small piece of land with alluvial soil located close to Yamuna River for the first time on variety Basarai and isolated a strain Erwinia carotovora from rotting parts of rhizome. Shillingford (1974) observed bacterial rhizome rot on a plant of Valery cultivar at Orange River Experimental Station, Jamaica early in 1970. Chattopadhyay and Mukherjee (1986) undertook a survey on the occurrence of the disease in West Bengal and reported that, the disease was prevalent in Karimpur area of Nadia district and spread to many other villages through planting materials. Nagaraj $e t$ al., (2012) reported that, the disease incidence was ranged from 30-35 per cent in the districts of Bangalore and Kolar of Karnataka on two popular varieties of banana G-9 and Robusta. 
Table.1 Survey on tip-over disease incidence of banana in Koppal, Shimoga, Chitradurga and Ballari districts

\begin{tabular}{|c|c|c|c|c|c|c|}
\hline $\begin{array}{l}\text { Sl. } \\
\text { No }\end{array}$ & Districts & Taluks & Villages & Variety & $\begin{array}{l}\text { No. } \\
\text { of } \\
\text { Plots }\end{array}$ & $\begin{array}{l}\text { Disease } \\
\text { Incidence } \\
\text { (\%) }\end{array}$ \\
\hline \multirow[t]{4}{*}{1} & \multirow[t]{4}{*}{ Koppal } & \multirow[t]{2}{*}{ Koppal } & Muddaballi & G-9 & 3 & 20.35 \\
\hline & & & Hatti & G-9 & 3 & 15.50 \\
\hline & & \multirow[t]{2}{*}{ Gangavati } & Bennur & G-9 & 3 & 11.25 \\
\hline & & & Challur & Local & 3 & 4.89 \\
\hline \multirow[t]{4}{*}{2} & \multirow[t]{4}{*}{ Shimoga } & \multirow[t]{2}{*}{ Shimoga } & Haramaghatta & G-9 & 4 & 7.33 \\
\hline & & & Bullapur & G-9 & 3 & 16.67 \\
\hline & & \multirow[t]{2}{*}{ Sagar } & Analekoppa & G-9 & 3 & 4.26 \\
\hline & & & Adur & G-9 & 4 & 8.35 \\
\hline \multirow[t]{4}{*}{3} & \multirow{4}{*}{$\begin{array}{l}\text { Chitradurg } \\
\text { a }\end{array}$} & \multirow[t]{2}{*}{ Hiriyur } & Dharmapura & G-9 & 3 & 6.65 \\
\hline & & & Alur & G-9 & 3 & 4.75 \\
\hline & & \multirow[t]{2}{*}{ Holalkere } & Garaga & G-9 & 3 & 7.23 \\
\hline & & & Budipura & G-9 & 4 & 8.48 \\
\hline \multirow[t]{4}{*}{4} & \multirow[t]{4}{*}{ Ballari } & \multirow[t]{2}{*}{ Hospet } & Kamalapura & G-9 & 4 & 6.43 \\
\hline & & & Bukkasagara & G-9 & 3 & 2.95 \\
\hline & & \multirow[t]{2}{*}{ Sandur } & Gollalingamanahalli & Local & 3 & 2.36 \\
\hline & & & Ankamanahal & G-9 & 3 & 1.15 \\
\hline
\end{tabular}

Table.2 Mean disease incidence of tip-over of banana in different districts of Karnataka

\begin{tabular}{lll}
\hline District & Taluk & $\begin{array}{l}\text { Disease incidence } \\
\mathbf{( \% )}\end{array}$ \\
Koppal & Koppal & 17.92 \\
& Gangavati & 8.07 \\
& Mean & 12.99 \\
\hline Shimoga & Shimoga & 12.0 \\
& Sagar & 6.30 \\
& Mean & 9.15 \\
\hline Chitradurga & Hiriyur & 5.7 \\
& Holalkere & 7.8 \\
& Mean & 6.75 \\
\hline Ballari & Hospet & 4.69 \\
& Sandur & 1.75 \\
& Mean & 3.22 \\
\hline
\end{tabular}


Similarly, present survey report indicated the more prevalence of disease on G-9 variety. Vijayalaxmi et al., (2012) have conducted an intensive roving survey to record the tip over incidence in Northern parts of Karnataka and reported the disease incidence in all the locations surveyed in a range of 4.25 to 65.28 per cent. Maximum disease incidence was 40.37 per cent recorded in Bijapur district followed by Bagalkot (23.72\%). Minimum disease incidence of 5.36 per cent was noticed in Dharwad district. The same trend was noticed in the present survey with highest tip over incidence at Koppal district followed by Shimoga. Lowest incidence was observed in Ballari district.

\section{References}

Chattopadhyay, P. K. and Mukherjee, N. 1986. A pseudostem rot of banana due to Erwinia chrysanthemi pv. paradisiaca, Curr. Sci., 55: 789-790.

Edward, J, C., Tripathi, S. C. and Singh, K.P. 1973. Observations on "Tip-over" disease of banana in Allahabad. Curr. Sci., 42: 696-697.

Hildreth, R.C. 1962. Studies on bacterial rhizome rot of banana. Rev of Plant Pathol, 42:79.

Khan, A. N. A and Nagaraj, M. S. 1998.
Occurrence of new bacterial disease on banana in Karnataka,P.32: In Ann. Meet. Symp. on Integrated Disesae Management and Crop Loss Assessment, Indian Phytopathological Society (Southern Chapter), UAS, Bangalore, held on December 10-12, p.73.

Nagaraj, M. S., Umashankar, N., Palanna, K. B. and Khan, A. N. A. 2012. Etiology and management of tip-over disease of banana by using biological agents, Int J. Adv. Bio. Res., 2(3): 483-486.

Shillingford, C. A. 1974. Bacterial rhizome rot of banana in jamaica, Pl. Dis Rep., 58: 214-218.

Stover, R.H. 1959. Bacterial rhizome rot of banana. Phytopathology, 49: 290-292.

Vijayalaxmi, S. T., Ravikumar, M. R., Benagi, V. I., Virupakshaprabhu, H., Wali, S.Y. . Pawar K.N. and Lingaraju, S. 2012. Survey on the tip over disease of banana caused by Erwinia carotovora subsp. carotovora (Jones) Holland in Northern Karnataka. $J$. Agric. Sci., 27(3):353-354.

Wardlaw, C.W. 1950. Banana diseases VIII. Notes on the various diseases occurring in Trinidad. Trop Agric., 12:143-149.

\section{How to cite this article:}

Thiyagarajan, V., S.T. Yenjerappa, Gururaj Sunkad, D.S. Aswathanarayana, V. Karuppaiah and Shaila, H.M. 2017. Survey on Tip-over Disease of Banana caused by Erwinia carotovora subsp. Carotovora (Jones) Holland in Parts North Eastern Karnataka, India. Int.J.Curr.Microbiol.App.Sci. 6(6): 2973-2976. doi: https://doi.org/10.20546/ijcmas.2017.606.354 